\title{
Basis for the Design of Drive-In and Drive-Through Racking
}

\author{
Rodoljub Vujanac ${ }^{1 *}$, Nenad Miloradović ${ }^{1}$, Pavle Živković1 ${ }^{1}$ Luka Petrović ${ }^{1}$ \\ ${ }^{1}$ Faculty of Engineering/Mechanical Construction and Mechanization, University of Kragujevac, Kragujevac (Serbia) \\ Drive-in and drive-through accumulation racking systems are recommended for great amounts of goods with few \\ various units. According to the "First In, Last Out" - FILO and "First-In, First-Out" - FIFO principle, the palletized load \\ unit are stored into deep tunnels accessible by forklift trucks for handling operations. This allows exploiting as much room \\ as possible and eliminating the aisles traditionally required for manipulating purposes. This paper provides basic \\ information on the requirements, design and use of drive-in and drive-through racking systems in accordance with current \\ regulations and standards. Minimum required clearances and tolerances due to all influencing parameters for manually \\ operated systems are discussed.
}

\section{Keywords: Pallet racking, Drive-In, Drive-Through, Regulation, Standard}

\section{INTRODUCTION}

Within the most popular adjustable pallet racking configuration each pallet is accessible from an operating aisle. Conventional pallet racking tunnels systems connected in the block with loadable aisles are static accumulation system recommended for great amounts of goods with only few various units [1]. The main principle of this racks structure is to store pallets on deep rail beams, one after the other. The forklift truck drives into the rack aisle to position and reposition the pallet units. According to the "First-In, Last-Out" - FILO or "First-In, First-Out" FIFO principle there are two types of the rack configuration as shown on the layout in Fig. 1; Drive-In Rack (DIR) and Drive-Through Rack (DTR) [2]. DIR and/or DTR racks are systems of racking that provide blocks of storage where pallets are stored two or more deep and where access is gained by driving a forklift truck into a lane with pallets supported along their sides on beam rails supported from the uprights. In DIR system which provides FILO principle of functioning, the forklift truck drives into a lane and reverse out, allows loading and unloading from the same face of the rack structure. This method for storage products does not require monitoring of deadlines and therefore not necessarily the first pallet stored is the first taken. DTR system is very similar to DIR actually identical in the structure, but in functioning the forklift truck could drive through the line if there are no pallets in the line. DTR configuration which follows FIFO method for storage is mainly used in food and pharmaceuticals field. This method of storage allows loading of pallets from a front storage system and the discharge from the opposite side. For both types racking configuration can be typically four pallets in height, minimum two but usually three or more pallets in depth (recommended up to seven due to monitoring) and can be numerous bays wide. Drive-in \& drive-through racking can store up to $75 \%$ more pallets in the same space than adjustable racking - depending on the application [3]. The aim of this paper is to specify the basic on the requirements, design and use of drive-in and drive-through racking systems in accordance with current FEM regulations and EN standards.

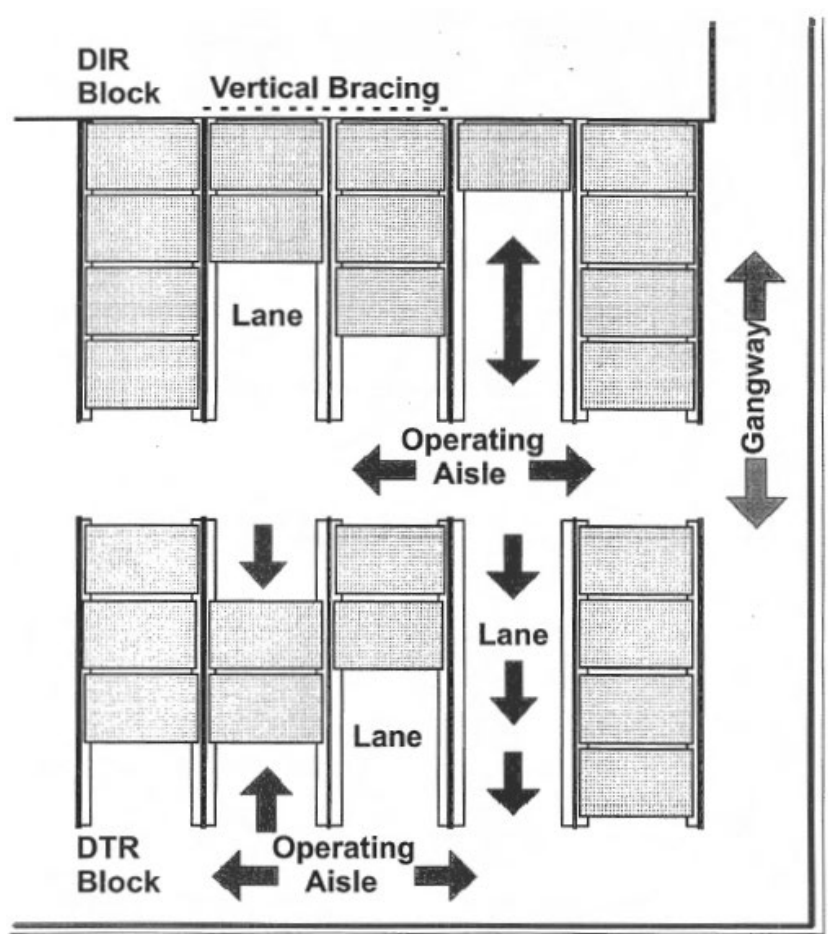

Figure 1: Layout of a Drive-In / Drive-Through Rack [2]

\section{RACK CONFIGURATION}

A typical DIR or DTR configuration is shown in Fig. 2 and Fig. 3. Both systems can be braced or unbraced. The upright frames (1) and/or mono post (2) connected with top-tie beams (3) form a basic spatial structure of the bloc of tunnels, i.e. group of interconnected lanes. The lane shown in Fig. 1 is the space between adjacent rows of uprights, perpendicular to the operating aisle shown in Fig. 1 too, allowing the forklift truck to enter the space and to pick and deposit unit loads (4) in depth and height. Spacer (5) is structural component joining a mono-post or upright frames with another upright frame in the down-line direction. Unit load, i.e. individual loaded pallet lies on the beam rails (6). Bracket (7) is an element with hooks which engage in holes or slots in the upright and supporting the beam rail and connecting it to the upright. Sometimes the beam rail may be bolted directly to the upright. Vertical bracing (8) as bracing structure in the vertical plane provides the rack stability in cross-line direction. Plane 
bracing (9) as top horizontal bracing structure provide down-line stability. In the down-line direction upright frame bracing (10) provides stability too. For an unbraced structure the cross-line stability is provided by the restraining effect of the top-tie beam to upright connection and of the upright to floor connection. Ground rails (11) fixed to the ground or directly to the uprights provides visual and mechanical guidance to help the operator to centre the forklift truck at the lane entry. Pallet entry guides (12) are elements positioned in front of each beam rail to help the operator to centre the unit load at the lane entry. Rear pallet stopper (13) mechanically prevents falling of the unit load at the end of line. Upright protector (14) is usually integral part of the baseplate on the entry uprights.

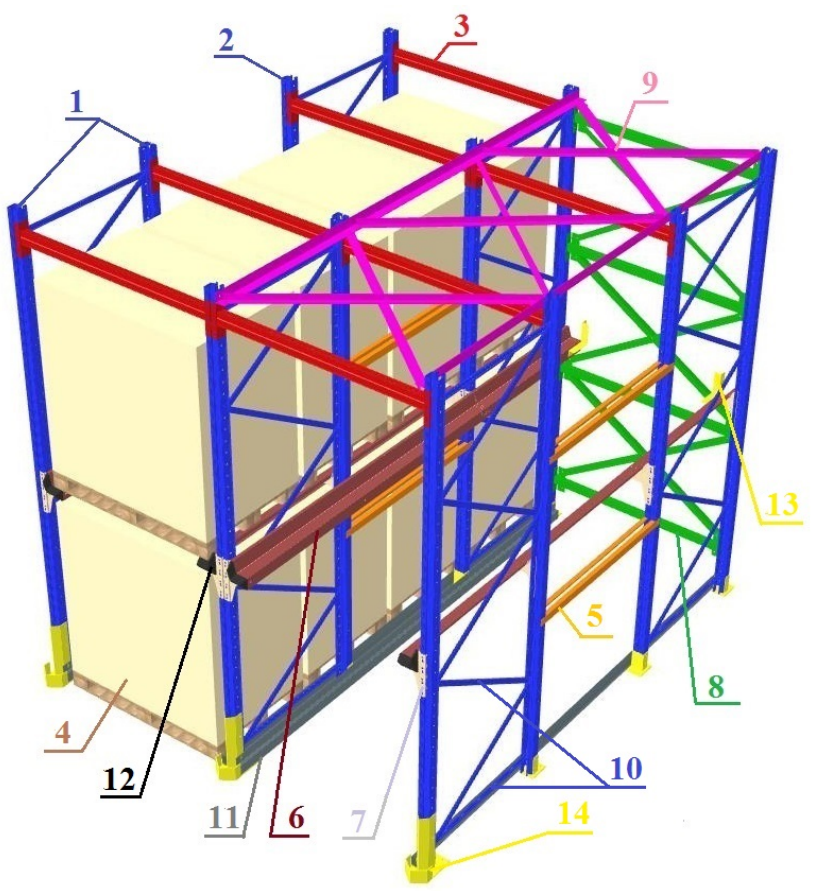

Figure 2: Drive-in rack configuration without bracing tunnel

In some unbraced configuration without vertical and plan bracing, especially for the DTR structures, extra stability of the system is provided by the "blind line" (15) where storage is prevented as shown in Fig. 3. In that case system must have at least one bracing tunnel [4]. The minimum width of the bracing tower should be:

$$
I_{c}=H / 10
$$

where is:

$I_{c}$ - bracing tunnel width, i.e. uprights distance;

$H$-drive-through height.

The horizontal action $\mathrm{T}$ to be considered at the top to design the bracing is:

$$
\begin{gathered}
T=F_{h} / N \\
F_{h}=N_{p} \cdot N_{l} \cdot N_{t} \cdot P / 200 \\
N=2 \cdot N_{s p} \cdot N_{c}
\end{gathered}
$$

where is:

$F_{h}$ - total horizontal action at the top of the drive in;

$N$ - total amount of vertical bracing;

$N_{p}$ - number of levels (brackets) in height;

$N_{l}$ - number of pallets in depth;

$N_{t}$ - number of tunnels;
$P$ - maximum pallet weight;

$N_{s p}$ - number of frames in depth;

$N_{c}$ - number of bracing tunnels.

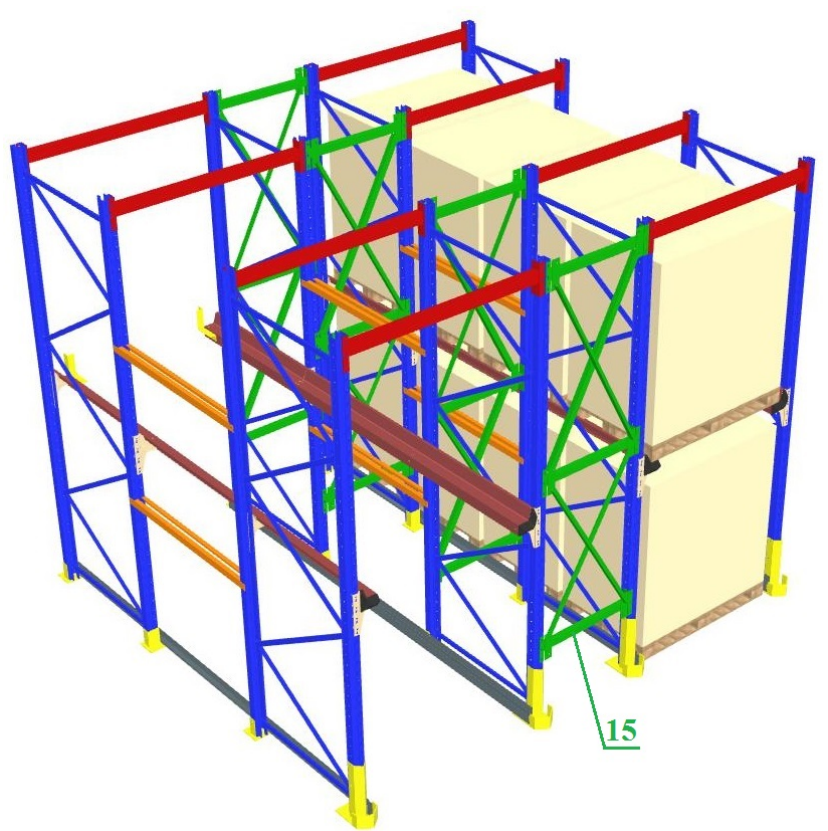

Figure 3: Drive-through rack configuration with bracing tunnel

\section{PARAMETERS INFLUENCING THE MINIMUM REQUIRED CLEARANCES}

Clearances are required to ensure safe operation condition in placing and picking by operators withing the storage system environment concerned and with the intended manually operated mechanical equipment [2]. Parameters influencing the minimum required clearances are as following:

- Floor flatness;

- Rack production tolerance;

- Rack installation tolerance;

- Rack deformation.

- Pallet tolerance;

- Lift truck properties;

\subsection{Floor Flatness}

For the system levels up to $6 \mathrm{~m}$ the floor flatness is not a critical parameter in the effective use of DIR or DTR provided that the floor flatness satisfies at least class FM3 according to EN 15620 [5] or DIN 182020 group 3 as an alternative. For the storage levels over $6 \mathrm{~m}$ the floor flatness should satisfy at least class FM3 according to EN 15620 or DIN 182020 group 4.

\subsection{Rack production and installation tolerances}

Rack production and installation tolerances are given in Table 1 and shown in Fig. 4 [2].

Table 1: Tolerance limit values for the installed rack [2]

\begin{tabular}{|c|c|c|}
\hline $\begin{array}{c}\text { Type of } \\
\text { tolerance }\end{array}$ & Description & $\begin{array}{c}\text { Limit } \\
\text { value }\end{array}$ \\
\hline \multicolumn{3}{|c|}{ Horizontal tolerances } \\
\hline$\delta \mathrm{A}_{\text {TOР }}$ & $\begin{array}{c}\text { Maximum variation in width of } \\
\text { individual lane (at top) }(\mathrm{mm})\end{array}$ & \pm 1.5 \\
\hline$\delta \mathrm{A}_{\mathrm{BOTTOM}}$ & $\begin{array}{c}\text { Maximum variation in width of } \\
\text { individual lane (at bottom) }(\mathrm{mm})\end{array}$ & \pm 5.0 \\
\hline
\end{tabular}




\begin{tabular}{|c|c|c|}
\hline$\delta \mathrm{A}_{\mathrm{T}}(\mathrm{n})$ & $\begin{array}{c}\text { Total deviation in rack length } \\
\text { cumulative at top or bottom (mm). } \\
\mathrm{n} \text { - number of lines }\end{array}$ & $\pm 2.0 \mathrm{n}$ \\
\hline$\delta \mathrm{E}$ & $\begin{array}{l}\text { Frame alignment in the down-line } \\
\text { direction (measured separately at top } \\
\text { and bottom) (mm) }\end{array}$ & \pm 3.0 \\
\hline $\mathrm{C}_{\mathrm{z}}$ & $\begin{array}{l}\text { Maximum out-of-plumb upright in the } \\
\text { cross-line direction }\end{array}$ & $1 / 500$ \\
\hline $\mathrm{D}$ & Rack depth (mm) & $\begin{array}{l} \pm 5.0 \text { per } \\
\text { frame }\end{array}$ \\
\hline $\mathrm{J}_{\mathrm{X}}, \mathrm{J}_{\mathrm{z}}$ & Maximum bow imperfection of upright & $1 / 1000$ \\
\hline $\mathrm{C}_{\mathrm{x}}$ & $\begin{array}{l}\text { Maximum out-of-plumb upright in the } \\
\text { down-lane direction }\end{array}$ & $1 / 500$ \\
\hline \multicolumn{3}{|c|}{ Vertical tolerances } \\
\hline $\mathrm{L}$ & $\begin{array}{l}\text { Maximum deviation of bracket level } \\
\text { with regard to the top of baseplate level } \\
(\mathrm{mm})\end{array}$ & $\pm \mathrm{H} / 250$ \\
\hline M & $\begin{array}{l}\text { Maximum deviation of pallet support } \\
\text { level between both sides of the pallet } \\
(\mathrm{mm})\end{array}$ & 6.0 \\
\hline
\end{tabular}
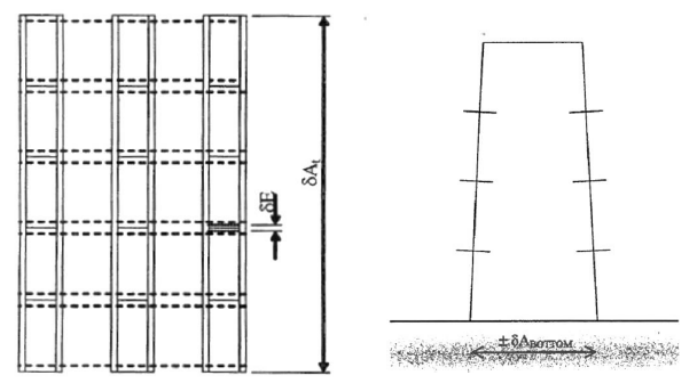

Variation of the clear lane width affects safo pallet bearing width

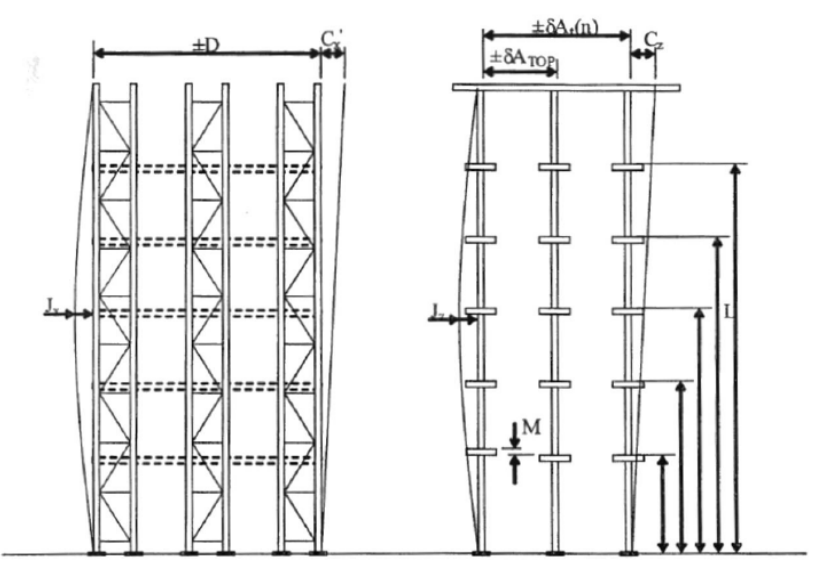

Figure 4: Relevant rack production and installation tolerances [2]

\subsection{Rack deformations}

The deformation limits and clearances are based on the operational method for placing pallets in DIR/DTR given in FEM 10.2.04 [6] and EN 15635 (2008) [7]. When a pallet is being placed into a drive-in rack, the following sequential loading activities take place as shown in Fig. 5 [6]:

a) The fork lift truck drives with a pallet to the pallet storage location, Fig. 5 (a).

b) The driver raises and manoeuvres the pallet into the racking lane, clear of the rack uprights, with the no forward tilt on the forks, at the required storage level and with the pallet load positioned centrally between the uprights, Fig. 5 (b). c) The truck is then driven forward to the set down position keeping the pallet and truck mast clear of contact with the beam rails or other parts of the drivein rack structure, Fig. 5 (c).

d) The driver lowers the pallet carefully onto the beam rails, releasing the load from the forks. Once in contact with the beam rails the pallet must not be slid or dragged along or across these supporting members.

e) The driver takes the forks out of the pallet, reverses the truck carefully back out of the lane and then lowers the forks.

In DIR or DTR racking the sequence of placement of loads shown in Figure 6 (a) and 6 (b) should be followed [6-7]. On the input cycle the first pallet is placed at position 1 and the rack is loaded from the bottom upwards and from the back outwards. On the output cycle the procedure is the exact reverse, from the top down working in towards the back of the drive-in rack. Beam rails of DIR / DTR racking fitted with integral or nonintegral sloping side guards should be loaded as shown in the sequence illustrated in Fig. 5.
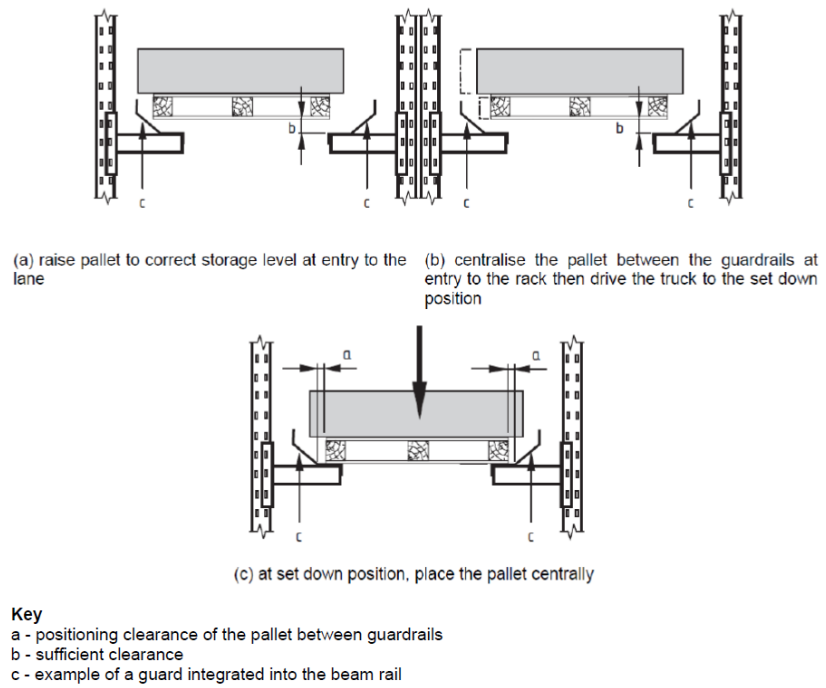

Figure 5: Correct sequence of loading for types of drive-in systems with guardrails [6-7]

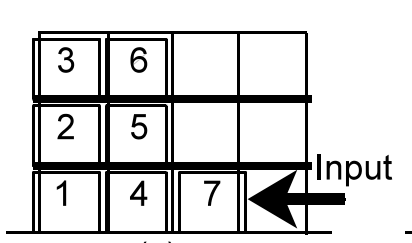

(a) (b)

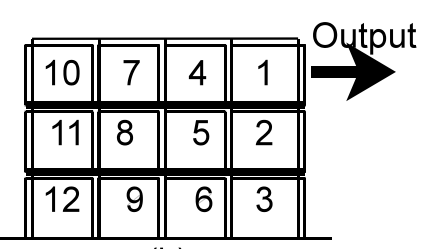

Figure 6: Loading (a) - Unloading (b) sequence for drive in racking [6-7]

The pallet shall be centralised between the selected lane uprights by first using the fork side shift, if necessary, to centralise the pallet in relation to the truck mast and then by steering the truck before the pallet enters the lane. The racking structure is not designed to provide pallet or truck mast guidance. Therefore minimum safe bearing of pallet on rails must be foreseen as show in Fig. $7[6]$. 


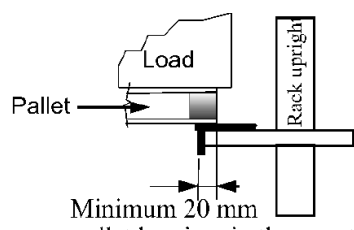

pallet bearing in the worst case on a beam rail with no guard with the pallet in the extreme left position

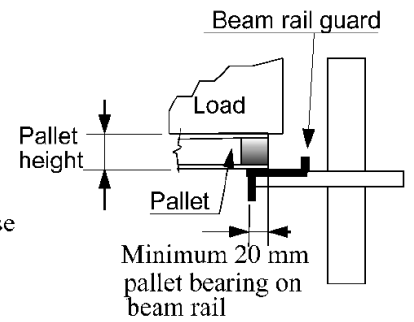

Figure 7: Minimum safe bearing of a pallet on DIR/DTR beam rails with the pallet in the extreme left position [6]

\subsection{Pallet specification for DIR/DTR racking}

The specification of pallets used in drive-in racking shall include for a quality of pallet that when loaded with the specified goods to be stored shall not deflect more than the pallet span/100 when supported on the beam rails with a minimum bearing on one side of 20 $\mathrm{mm}$, see Fig. 7. The pallet span is the nominal clear dimension between the beam rails. Timber pallet quality is extremely important for the safe operation of pallet racking and particularly drive-in racks. Weak pallets or damaged pallets (e.g., with broken bottom boards) should not be used neither should incorrect types of pallets. Advice on suitable pallet types can be obtained from prospective suppliers.

\subsection{Lift truck properties}

Lift truck shall be equiped with side-shift for operation at storage levels above $6 \mathrm{~m} \mathrm{[2].} \mathrm{This} \mathrm{assists} \mathrm{to}$ correctly deposit the pallet on the pair of beam rails and it is recommended for all applications. Mast stifness shall be in accordance with EN 15635 clause 8.7 [7]. The maximum lifting height shall be sufficient to allow driving down lane without touching the pallet rail. The lane width and detailing of the baseplate connection shall ensure that the lift truck can eneter and drive in a lane adequate clearances. Relevant truck dimensions are given in Fig. 8 as following:

1 - Between the outer tyre edges;

2 - Overall width;

3a - Width of cabin (standard);

$3 \mathrm{~b}$ - Width of cabin (special for DIR / DTR);

4 - Width of lower mast (including and attached equipment);

5 - Width of middle mast (if any, and including any attached equipment);

6 - Width of upper mast (including any attached equipment);

7 - Ground clearance;

8 - Height of overhead guard (cabin);

9 - Height of lower mast;

10 - Height of middle mast;

11 - Lift height.

The speed at which the lift truck is driven in the rack storage lanes is critical to the safe operation of the storage system [6]. To prevent the mast from flexing and swaying excessively on uneven floors and striking the beam-rails, the truck speed must be regulated by the driver to suit the floor flatness and the mast flexibility.

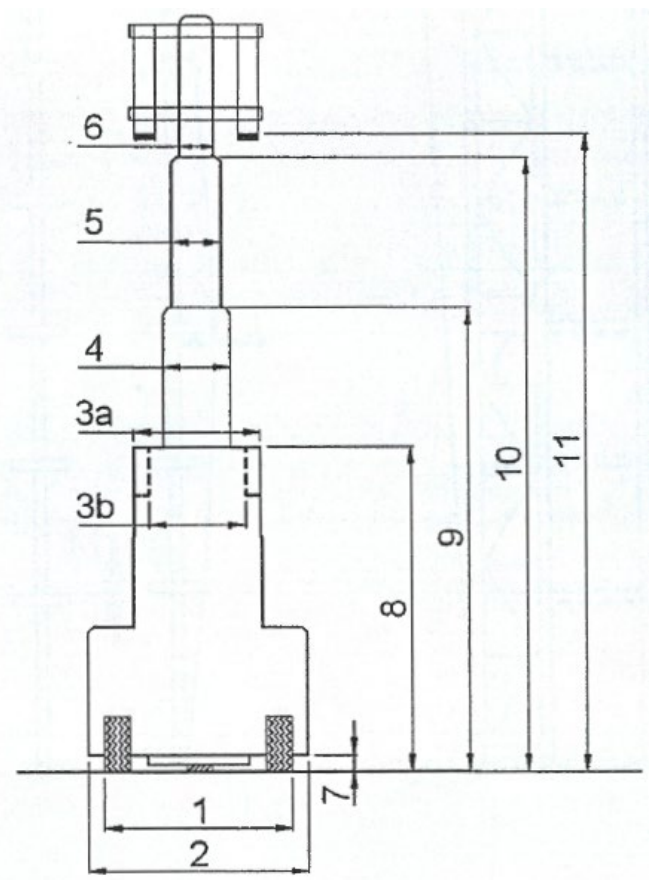

Figure 8: Relevant rtuck dimensions for the cross line direction [2]

\section{CLEARANCES}

The clearances detailed should be considered in relation to the overall measurements of the pallet and load (i.e. including any pallet load overhang) and the type of beam rail, with or without a pallet guide element [8]. With regard to the clearance consideration there are five potential critical positions as shown in Fig. 9 [2]:

- Pallet or truck body with respect to the baseplate, upright and floor rail (if present) (Item 1; clearances $a_{7}$ and $a_{8}$ in Fig. 10),

- Truck cabin in relation to the beam rail outer side (Item 2; clearance a9 in Fig. 10),

- Truck mast in relation to the beam rail (Item 3; clearance $\mathrm{a}_{10}$ in Fig. 10)

- Pallet edge with regards to the pallet beam rail guard, if any (Item 4; clearance $1 / 2 \mathrm{a}_{5}$ in Fig. 11)

- Pallet load with regard to the upright (Item 5; clearance $a_{1}$ in Fig. 11).
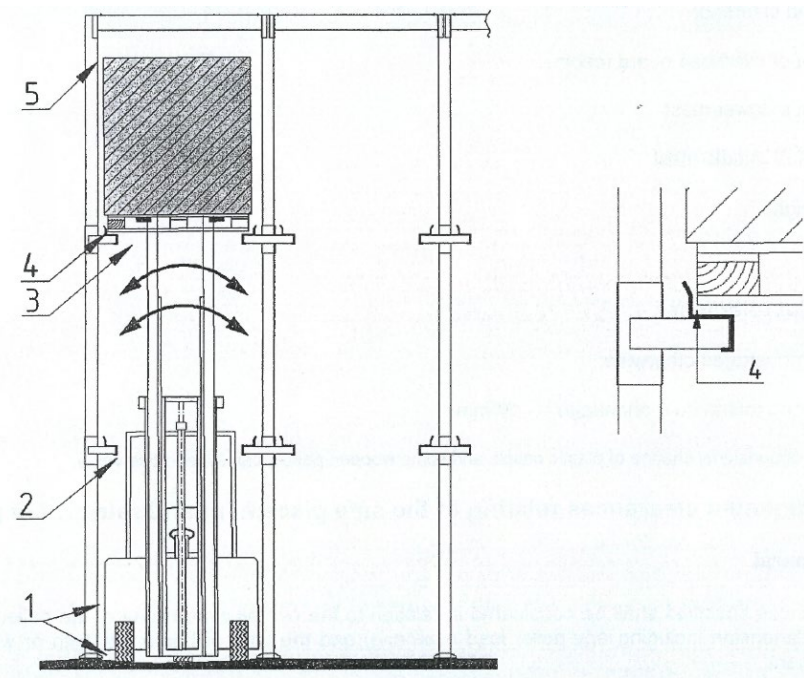

Figure 9: Relevant positions for the specification of minimum clearances [2] 
The spacing between the sides of the pallet (including the pallet load) and the uprights should at least be in accordance with the following (see Fig. 11 (a), dimensions $\mathrm{a}_{1}$ and $\mathrm{a}_{2}$ ) [8]:

- High drive-in racks (top bracket level higher than about $5 \mathrm{~m}$ ) and/or relatively high turnover, $100 \mathrm{~mm}$;

- Other cases $75 \mathrm{~mm}$.

The spacing between a pair of beam rails shown in Fig. 10, $\mathrm{a}_{11}$, in a drive-in rack should be so chosen, that the bearing width, dimension $\mathrm{a}_{6}$ (see Fig. 11) of the pallet bearer on the beam rail is at least $20 \mathrm{~mm}$ [8].

Account must be taken of the most unfavourable placement of the pallet (pallet on one side against an upright or side guide rail) and the maximum lateral bowing deflection, $\Delta \mathrm{a}_{11}$, of the uprights (see Fig. 11 (a) and (b) and the width tolerance, $\mathrm{W}_{\mathrm{t}}$, of the bay (see Fig. 12).

The spacing between the pallet load and the upright during placement of the pallet should be at least 45 $\mathrm{mm}$ (see Fig. 11, dimension $\mathrm{a}_{3}$ ) when the pallet is positioned $25 \mathrm{~mm}$ above the horizontal support surface of the beam rail.

The spacing between the side guide rail, when present, and the uprights should be at least $45 \mathrm{~mm}$ at the point of contact of the pallet and beam rail guide element when the pallet is positioned $25 \mathrm{~mm}$ above the horizontal support surface of the beam rail in Fig. 11, dimension $\mathrm{a}_{4}$.

The spacing between the wheels of the fork lift truck and the side of the base plates should be at least 75 mm (see Fig. 10, dimensions $\mathrm{a}_{7}$ ).

The spacing between the wheels or body of the fork lift truck and the side of the uprights should be at least $75 \mathrm{~mm}$ (see Fig. 10, dimension $\mathrm{a}_{8}$ )

The following minimum clearance dimensions each side must be taken for the spacing between the fork lift truck and the side of the pallet beam rails.

- At the lowest bracket level, 75mm (see Fig. 10, dimension a9);

- Other bracket levels, $100 \mathrm{~mm}$ (see Fig. 10, dimension $\mathrm{a}_{10}$ ).

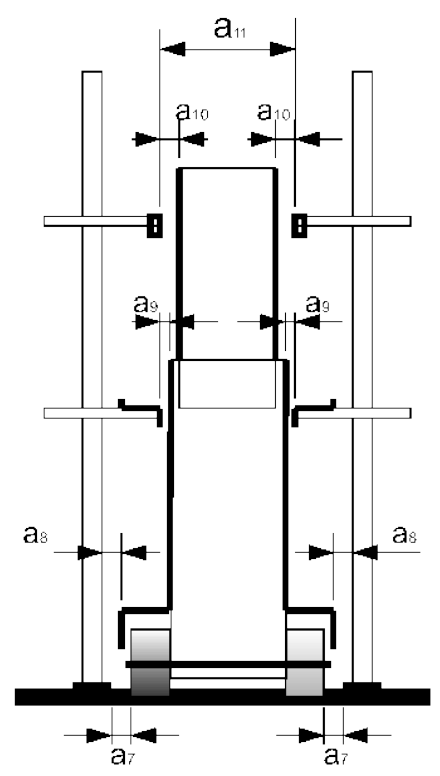

Figure 10: Truck aisle clearances and pallet rail spacing dimensions with respect to fork lift truck [8]
The spacing, as, between the pallet and a side guide rail should be at least $50 \mathrm{~mm}$ when the pallet is positioned $25 \mathrm{~mm}$ above the horizontal support surface of the beam rail and touching one of the guide rail elements, see Fig. 11(b).

The spacing, $b_{1}$, between the top of the pallet load and bottom surface of the rack cantilever bracket or beam rail when the pallet is seated on the horizontal support surface of the beam rail, should be as for dimension $\mathrm{Y}_{3}$ for APR Class 400 [8].

The spacing between pallets in determining the overall rack bay depth should be at least $25 \mathrm{~mm}$ [8].

The pallet span $\mathrm{a}_{11}$ is the nominal clear dimension between the beam rails, see Fig. 10.

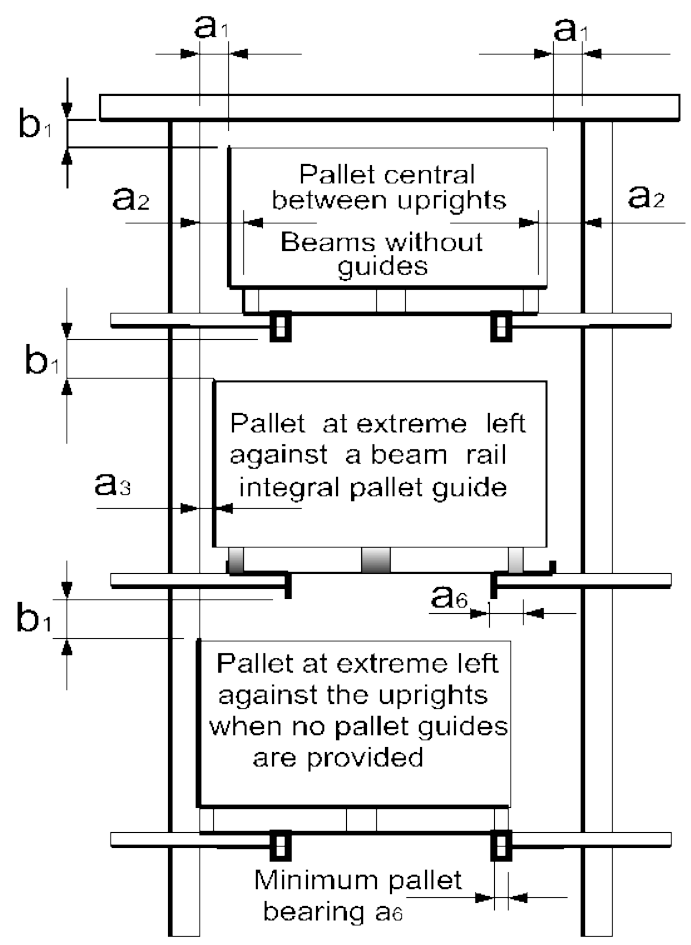

(a) Placement of pallets

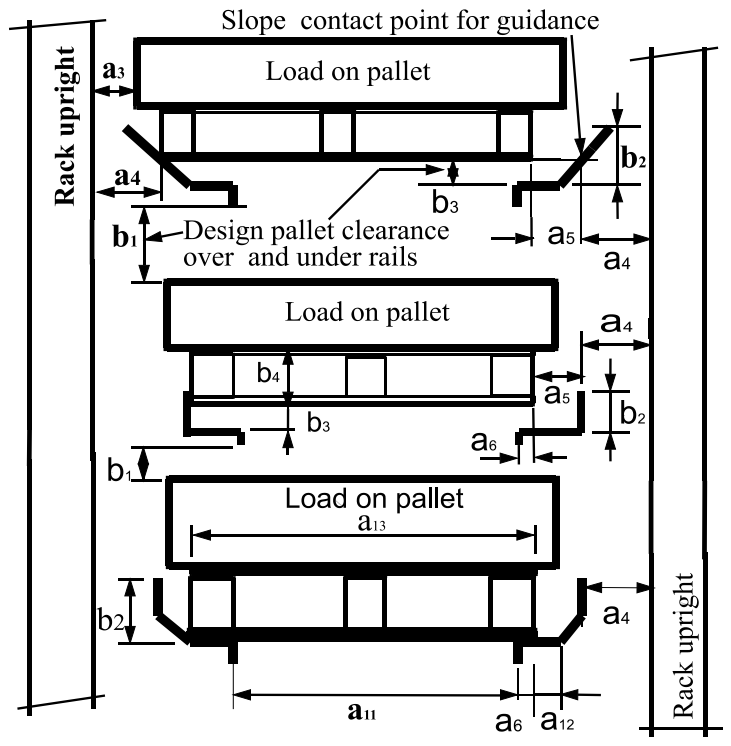

(b) Beam rail guide detailes

Figure 11: Vertical and horizontal clearances for drive in racking with regard to the unit load [8] 


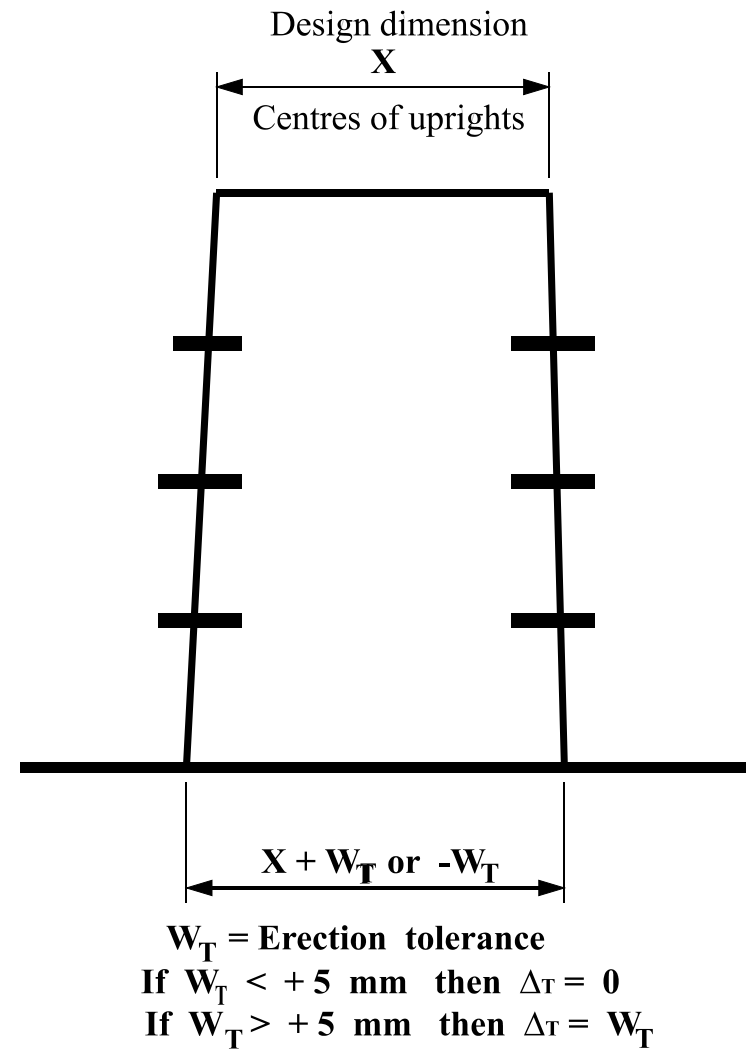

Figure 12: Truck aisle clearances and pallet rail spacing dimensions with respect to erection tolerance [8]

For drive-in racks, the maximum lateral bending of the uprights as a consequence of pallets already in place should be considered. It is necessary to determine the sum of the bending deflections $\Delta \mathrm{a}$ of adjacent uprights towards each other, (dimension $\Delta \mathrm{a}$ according to the FEM recommendations in preparation for drive-in racks). This dimension $\Delta \mathrm{a}_{11}$ (see Fig. 13) can assume a value of up to $\pm 30 \mathrm{~mm}$, depending upon the rack upright properties, overall height, bracket length and pallet load.

The width tolerance $\mathrm{W}_{\mathrm{T}}$ between consecutive uprights together with $\Delta \mathrm{a}$ should also be considered in assessing the horizontal beam rail pallet support dimensions $\mathrm{a}_{5}$ and $\mathrm{a}_{6}$.

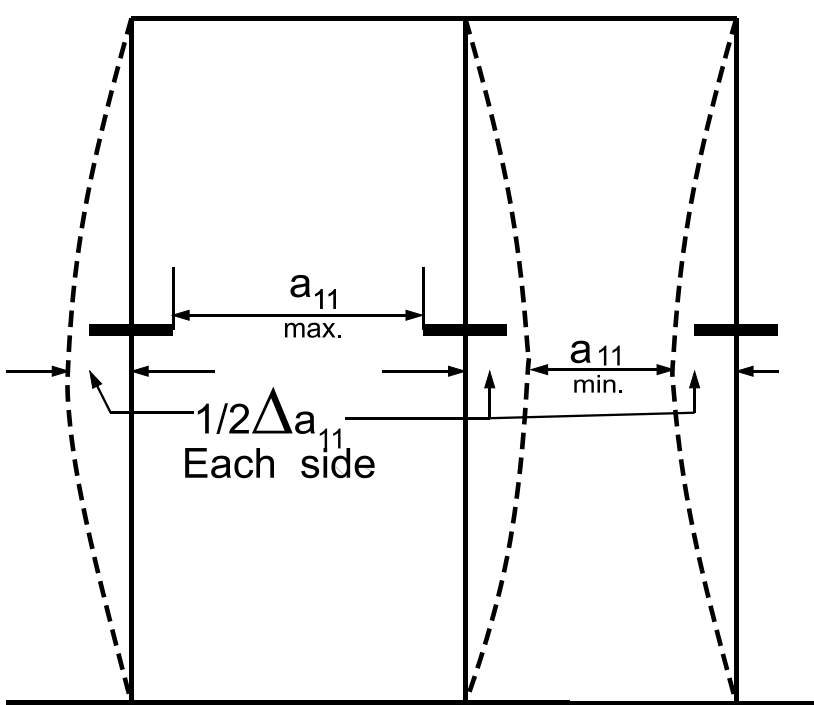

Fig 13: Measurement of upright bending deflection [8]
The minimum bearing of the pallet on the right hand rail with the pallet hard over to the left side is shown in Fig. 14 as $20 \mathrm{~mm}$.

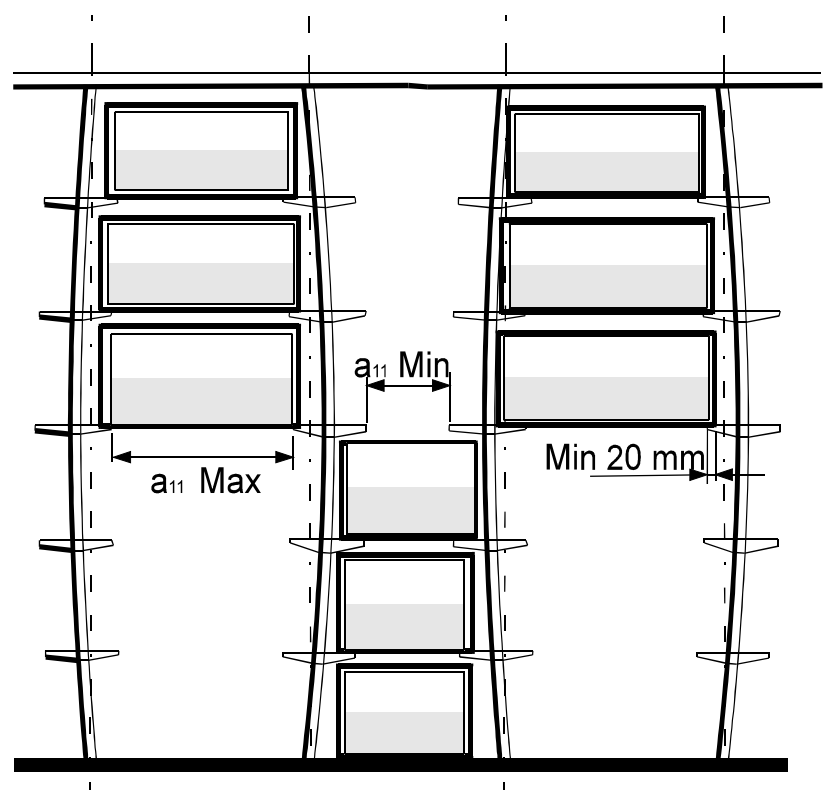

Figure 14: Uprights Lateral bending deflection [8]

\section{CONCLUSIONS}

Drive-in and or drive-through racking system is strongly represented high density storage solution especially in refrigerated chambers, food warehouses, water and drink manufacturers and distribution centres. The palletized load units usually are stored into deep tunnels accessible by forklift trucks for handling operations. This allows exploiting as much space as possible and eliminating the aisles traditionally required for service purposes in adjustable pallet racking configurations. The configuration chosen must be right for the realistic product movement through the warehouse. Firstly, adequate principle of functioning FIFO or FILO must be satisfied referring to the stored goods. Then, some logistic consideration must be taken into account because if the system is much too deep, or much too high, it will increase operating costs, because of the time required to take load from the storage, or to put load in the storage. This is simply because operation of a forklift truck within a rack system must be done carefully and relatively slowly in comparison to the lift trucks normal operating speed. After the proper configuration is selected, unit load characteristics determine the required design of the components used. Most common materials used in the rack structures are light cold-formed profiles or hot-rolled steel in standard structural shapes. At the end the functionality of DIR and/or DTR systems can be additionally improved with automatization of handling process where adequate systems can better achieve results instead of traditional fork lift truck. Introduction of radio shuttle as standard equipment and its improvement with shuttle carriage together with vertical reciprocating conveyors brings to the fully automatization of the system. Beside of faster handling thsi system allow further increases in productivity, reduced damages, improved safety and ergonomics. 


\section{REFERENCES}

[1] R. Vujanac, "Razvoj metodologije za projektovanje i proračun nosećih elemenata skladišnih sistema", In Serbian, MSc Thesis, University of Kragujevac, (2007)

[2] FEM 10.2.07, "Drive-in and Drive-Through Racking Drive-in Design Code", European Racking Federation. Hitchin (England), (2012)

[3] R. Vujanac, R. Slavković and N. Miloradović, "Automatization of Multi-Depth High-Density Storage System," Metalurgia Inetrnational, Vol. 18 (8), p. 49$55,(2013)$

[4] Dalmine Logistics Solutions, "DRIVE IN" Technical Manual, Piacenza, (2015)

[5] EN 15620, "Steel static storage systems - Adjustable pallet racking - Tolerances, deformation and clearances", European Committee for Standardization. Brussels (Belgium), (2008)

[6] FEM 10.2.04, "Guidelines for the Safe Use of Static Steel Racking and Shelving - User's Code", Fédération Européenne de la Manutention (FEM), Section X. Brussels (Belgium), (2000)

[7] EN 15635, "Steel static storage systems - Application and maintenance of storage equipment", European Committee for Standardization. Brussels (Belgium), (2008)

[8] FEM 10.2.03, "Guidelines for Specifier's of Static Steel Racking and Shelving - Specifier's Code", Fédération Européenne de la Manutention (FEM), Section X. Brussels (Belgium), (2000)

\section{Osnova za projektovanje Drive-in i drive-through regala}

Rodoljub Vujanac ${ }^{1 *}$, Nenad Miloradović ${ }^{1}$, Pavle Živković ${ }^{1}$, Luka Petrović ${ }^{2}$

${ }^{1}$ Fakultet inženjerskih nauka Univerziteta u Kragujevcu, Kragujevac (Srbija)

Drive-in $i$ drive-through akumulacioni regali se preporučuju za velike količine robe sa nekoliko različitih jedinica. Prema principima „Prvi ušao, poslednji izašao“ - FILO i „Prvi ušao, prvi izašao“ - FIFO, paletizovana jedinica tereta se skladišti u duboke tunele do kojih mogu da pristupe viljuškari za rukovanje. Ovo omogućava iskorišćavanje što je moguće više prostora i eliminisanje prolaza koji su tradicionalno potrebni za svrhe manipulacije. Ovaj rad daje osnovne informacije o zahtevima, projektovanju $i$ upotrebi drive-in $i$ drivethrough sistema regala $u$ skladu sa važećim propisima $i$ standardima. Razmatraju se minimalni potrebni zazori $i$ tolerancije zbog svih uticajnih parametara za sisteme sa ručnim upravljanjem.

Ključne reči: Paletni regali, Drive-In, Drive-Through, Regulacija, Standard 